\title{
Atasözü ve Deyimlerin Çoklu Ortam Materyalleriyle Somutlaştırılmasının Okul Öncesi Eğitime Etkisi
}

\author{
Abdullatif Kaban* - Ayhan Bulut** \\ * Dr. Öğr. Üyesi, Bayburt Üniversitesi, Bayburt Eğitim Fakültesi, Bayburt / Türkiye \\ E-Posta: abdullatif.kaban@gmail.com \\ ORCID: $\underline{0000-0003-4465-3145}$ \\ ** Dr. Öğr. Üyesi, Bayburt Üniversitesi \\ E-Posta: ayhanbulut44@hotmail.com \\ ORCID: 0000-0001-6482-8032
}

Öz

Bu araştırma, okul öncesi eăitim döneminde çocuklara atasözü ve deyimleri öğretmede öğretmenlerin çoklu ortam materyallerinden yararlanmasının çocuklardaki atasözü ve deyimlerle ilgili öğrenme düzeylerini ne yönde etkileyeceğini belirlemeyi amaçlamaktadır. Bu araştırma uygulamalı betimsel bir çalışmadır. Araştırma kapsamında nitel veri toplama yöntemlerinden biri olan odak grup görüşmesi yöntemi kullanılmıştır. Bu araştırma 2019-2020 eğitim öğretim yılının ilk yarısında Erzurum il merkezinde okul öncesi eğitim kurumlarına devam eden 60-69 aylık yaş aralığına sahip 10 çocuğun katılımı ile gerçekleştirilmiştir. Çalışma kapsamında veriler odak grup görüşmesiyle toplanmıştır. Odak grup görüşmesinde çocuklara atasözleri ve deyimleri anlatan çoklu ortam videoları izletilerek bir etkinlik yapılmiştır. Görüşme esnasında veri toplama aracı olarak sekizer atasözü ve deyimden oluşan soruları bulunduğu yapılandırılmış görüşme formu kullanılmıştır. Çocuklara etkinlik öncesinde ve sonrasında sorulan sorular ile bu atasözleri ve deyimlerden ne anladı̆̆ ölçülmüştür. Araştırma kapsamına giren atasözleri ve deyimlere ait veriler ayrı ayrı başlıklar halinde incelenmiştir. Verilerin çözümlenmesinde içerik analizi yöntemi kullanılmıştır. Sonuç olarak atasözleri ve deyimlerin okul öncesi eğitim döneminde çocuklara öğretmenler tarafindan çoklu ortam materyalleri kullanılarak öğretilmesi onların atasözleri ve deyimleri daha iyi anlamalarını sağladığı, öğrenmelerini kolaylaştırdığı belirlenmiştir.

Anahtar Kelimeler: Okul öncesi eğitim, çoklu ortam materyalleri, atasözü, deyim, somutlaştırma 


\title{
The Effect of Embodying Proverbs and Idioms with Multimedia Materials on Preschool Education
}

\begin{abstract}
This research aims to determine how teachers' use of multimedia materials in teaching proverbs and idioms in preschool education will affect the learning levels of children about proverbs and idioms. This research was an applied descriptive study. The focus group interview method, one of the qualitative data collection methods, was used in the study. This research was carried out in Erzurum city center with the participation of 10 children, who are in the 60-69 month age range, who attend preschool education institutions in the first half of the 2019-2020 academic year. Within the scope of the study, the data were collected through focus group discussion. In the focus group meeting, an event was made by showing the multimedia videos about the proverbs and idioms to the children. During the interview, a structured interview form with questions consisting of eight proverbs and eight idioms was used as the data collection tool. What they understood from these proverbs and idioms were measured by the questions asked to the children before and after the activity. The data of proverbs and idioms included in the research were examined in separate titles. The content analysis method was used to analyze the data. As a result, it has been determined that teaching proverbs and idioms to children by using multimedia materials in the preschool education period helps them to understand the proverbs and idioms better and facilitates their learning.
\end{abstract}

Keywords: Preschool education, multimedia materials, proverb, idiom, embody. 


\section{Giriş}

İnsanlığın varoluşuyla beraber ortaya çıkan, geçmiş ile günümüz arasında toplumların birbirlerini anlamalarını ve iletişim kurmalarını sağlayan kültürün en önemli yapı taşlarından biri de dildir. Toplumların geçmişten günümüze kadar içinden geçtiği tarihsel süreci gösteren ve onların geleceğine dair ışık tutan sözlü ve yazılı kültürel öğelere dair ne varsa orada o toplumun kültürü ve o kültürün en önemli parçası olan dilin varlığından söz etmek mümkündür. Her toplumun kendi dilinde anlam bulan kültürel dokularından izler taşıyan atasözleri ve deyimler yer almaktadır.

Duygu, düşünce ve isteklerin yazılı ve sözlü olarak dile getirilmesi olarak bilinen dil, iletişimin en önemli öğesidir. Bireyler duygu, düşünce ve hayallerini dil aracılığıyla dile getirirler. Düşüncenin yansıması olan dil aynı zamanda kültür taşıyıcılığının yegâne vasıtasıdır. Dilin önemli anlatım seçeneklerinden olan atasözleri ve deyimler, toplumun sosyal ve kültürel değerlerini yansıtan, kuşaklararası kültür aktarımında çok önemli rol oynayan birbirlerini tamamlayan unsurlardır (Bulut, 2013). “Atasözleri, bir ulusun geniş halk kitlelerinin yüzyıllar boyunca yaşadığı deneyim, gözlem ve bunlardan doğan düşüncelere dayanan; genel kural ve düstur niteliği taşıyan veya bir doğruyu ortaya koyan; söyleyeni unutulduğu için halkın ortak malı olan; kısa, özlü ve kalıplaşmış; içinde yargı bulunan bir tümce değerindeki sözlerdir" (Aktaş, 2004). Atasözleri dünyanın her dilinde vardır; genellikle bir cümle biçiminde oluşarak bir yargı anlatan, kimi zaman ölçü ve uyakla, söyleniş açısından daha etkili olmaya yönelik sözlerdir" (Aksan, 2000). Atasözlerinin toplumsal düzeni sağlamada ve toplumları yönlendirmede hukuk kuralları kadar etkili oldukları, toplumun bu ihtiyacını karşıladıkları görülür" (Artun, 2004). Deyimler de atasözleri gibi kısa özlü sözlü anlatım araçlarıdır. Deyimler, kalıplaşmış sözlerdir. "Deyimler asıl anlamlarından uzaklaşarak yeni kavramlar meydana getiren kalıplaşmış sözlerdir. İki veya daha çok kelimeden kurulu bir çeşit dil ifadesi olan bu sözler duygu ve düşüncelerimizi, dikkati çekecek biçimde anlatan isim, sıfat, zarf, basit ve birleşik fiil görünüşlü gramer unsurlarıdır" (Elçin, 1986).

Toplumlar birer dil ürünü olan atasözleri ve deyimler aracilı̆̆ıla da kültürel bilgi ve tecrübelerini gelecek kuşaklara aktarırlar (Dik, 2010). Hiç şüphesiz ki tarihin en eski devirlerinin anlayışı ve duyguları, bir milletin canlı 
dilinde ve bu dilde oluşan unsurlarda kendi yansımasını bulmaktadır (Hac1yev, 1990). Bir milletin dilinde oluşan deyimler ve atasözleri tarihî enginlik, estetik güzellik ve bir milletin anlayışının her yönüyle derinliğini yansıtan en değerli hazinelerdir (Cemşidov, 1996). Başka bir ifadeyle, atasözleri; ait olduğu toplumun zihin yapısını, estetik anlayışını, iletişimsel ve davranışsal normlarını ve bu konularda toplumun genel duygularını ve düşünüş tarzını yansitır (Duman, 2012). Hangi çalışma veya disiplin alanında olursa olsun eğitimciler, toplumların genel ahlaki değer ve yargılarını çocuklara öğretirken eğitim ortaminda sıklıkla atasözleri ve deyimlere yer vermektedirler. Toplumsal yaşam düzen içerisinde, kültürel değerlerin kuşaktan kuşağa aktarılmasında bu denli önemli olan atasözleri ve deyimlerin çocuklara okul öncesi eğitim döneminde öğretilmeye başlanması gelecek açısından sağlam bir toplum düzeni için oldukça önemli olduğu görülmektedir.

Okul öncesi eğitim döneminde çocuklara atasözleri ve deyimlerin çocukların ilgisini ve dikkatini çekecek şekilde verilmesi, atasözleri ve deyimlerin onları eğlendirirken öğretilmesi, öğrenme ve öğretme süreçlerinin bu şekilde planlanması ve organize edilmesi için çoklu ortam materyallerinden ve teknolojinin imkânlarından yararlanılması bu anlamda çocuklara verilecek eğitimin içeriğini daha zengin ve daha nitelikli hale getirecektir.

En basit anlamıyla çoklu ortam; göze, kulağa ve dokunma duyusuna hitap eden çevrelerdir. Çoklu ortamla öğrenme ise öğrenenin bilişsel bilgi işleme sisteminde gerçekleşen bir öğrenme sürecidir (Mayer, 2009). Farklı ortamların bir araya getirilmesi ile oluşturulan çoklu ortam; iletilerin aynı anda birden fazla duyuya hitap edebilecek şekilde tasarlanmasını sağlar (Jonassen, Howland, Moore, ve Marra, 2003). Rogers (2001)'a göre çoklu ortamlar resim, video, ses, animasyon ve simülasyonların birlikte kullanılmasıyla oluşur. Schwier ve Misanchuk (1994) çoklu ortamı, birbiriyle bütünleşmiş farklı kaynakları içeren bir öğretim programı şeklinde ifade etmiştir. Tüm bu nedenlerle çoklu ortamlar, yüksek etkileşim düzeyi olan ortamlardır ve öğrenciler bu ortamlarda, bilgiler arasında gezinebilir ve öğrenmek istedikleri bilgileri seçebilirler (Kılıç-Çakmak, 2007; Lever-Duffy, McDonald, ve Mizell, 2003). Teknolojinin sunduğu çoklu ortam materyallerinden yararlanarak, kültürün önemli bir parçası olan dil gelişimine katkı sağlamak ve okul öncesi eğitim döneminde çocuklara atasözleri ve deyimleri daha somut ve anlaşılabilir şekilde öğretmek kültürel değerlerin gelecek kuşaklara daha kalıcı bir şekilde aktarılması açısından da oldukça önemlidir. Okul öncesi dönem, çocuğun, 
içinde yaşadığı toplumun değer yargılarını ve o toplumun kültürel yapısına uygun davranış ve alışkanlıkları kazanmaya başladığı bir dönemdir (Bilir ve Bal, 1989). Bu dönem eğitim açısından son derece önemlidir ve bilim insanları tarafından "kritik dönem" olarak adlandırılmaktadır (Önder, 2011). Bu bağlamda okul öncesi eğitimde çocukların dil gelişimine katkıda bulunmak, kültürel değerlerin taşıyıcısı olan atasözleri ve deyimleri somutlaştırarak öğretmek adına son derece önemli bir başlangıç noktası olabilir. Okul öncesi eğitim döneminde çocukların bilişsel öğrenme sürecini harekete geçirecek, birden fazla duyu organlarına hitap edecek, yeni öğrenmelerini kolaylaştıracak öğrenme ortamları oluşturmak gerekir. Bilişim teknolojisindeki hızlı ilerlemelerle birlikte, animasyon, ses, video, grafik gibi çoklu ortam materyallerinin kullanılması özellikle atasözü ve deyimler gibi çocuklar için soyut olan kavram ve olguların öğretilmesinde son derece önemli görülmektedir.

Atasözleri ve deyimlerin taşıdığı anlam toplumdan topluma, yaşanılan coğrafyaya ve kültürel değerlere göre değişse de içerdiği mesajlar her zaman güncelliğini ve geçerliliğini korumuştur. Bu çalışmanın problem konusunu okul öncesi eğitim dönemi çocuklarının içinde bulunduğu bilişsel gelişim süreçleri itibariyle atasözleri ve deyimler gibi daha çok soyut öğrenmeler içeren kavram ve olguların öğretilmesinde çoklu ortam materyalleri kullanılarak somutlaştırmaya en fazla ihtiyaç duyulan bu dönemdeki çözüm arayışları oluşturmaktadır. Bu dönemde atasözleri ve deyimlerin çoklu ortam materyalleri kullanılarak çocuklara öğretilmesi onların dil gelişimlerine katkıda bulunmasının yanı sıra içinde yaşadıkları toplumun değer ve kültürünü tanımada ve anlamada büyük kolaylıklar sağlayacaktır.

2013 okul öncesi eğitim programı incelendiğinde, programda yer alan Türkçe etkinliği; "Türkçeyi doğru ve güzel konuşmaların sağlamak, sözcük dağarcıklarım geliştirmek ve iletişim becerilerini artırmak için planlanan etkinlikler" olarak tanımlanmıştır. Bu etkinliklerin amac1; "Türkçeyi düzgün kullanmalarını, sesleri çıkarmalarmı ve farklı söz dizimsel yapıları anlama ve kullanmaların, dinleme becerileri kazanmasml, duygu ve düşüncelerini sözel ve sözel olmayan yollarla ifade etmelesini, ses tonunu ayarlamasın ve sözcükleri doğru üretmesini sağlamaktır" şeklinde ifade edilmektedir (Milli Eğitim Bakanlığı, 2013). Türkçe etkinlikleri içerisinde belirtilen çocukların farklı söz dizimsel yapıları anlamalarına yönelik olarak yapılan etkinliklerin özellikle bilmeceler, tekerlemeler, atasözü ve deyimleri anlamaya yönelik etkinliklerden oluştuğu düşünülmektedir. Ayrıca okul öncesi eğitim programında yer alan müzik etkinliklerinde de eğitici 
ve öğretici çocuk şarkıları, ezgili saymaca, bilmece, tekerleme ve atasözleri ile çocuğun dil gelişimine katkı sağlamaya yönelik çalışmalardan oluştuğu görülmektedir. Okul öncesi eğitim döneminde çocuklara atasözleri ve deyimlerin nasıl ve ne şekilde öğretilmesi konusunda literatürde herhangi bir çalışmaya rastlanmamıştır. Bu nedenle bu araştırma okul öncesi eğitim döneminde çoklu ortam materyalleri kullanılarak atasözleri ve deyimlerin öğretilmesi açısından konuyla ilgili eğitim paydaşlarına alternatif bir bakış açısı kazandırması açısındanda önemli görülmektedir. Ayrıca okul öncesi eğitim programlarında yer alan çocukların dil gelişimine katkı sağlamayı amaçlayan Türkçe ve müzik etkinlikleri içerisinde geçen atasözleri ve deyimlerin anlamlarını çocukların anlaması çok daha açık ve anlaşılır hale getirebileceği açısından da önemlidir.

Okul öncesi eğitim döneminde çocuklara atasözleri ve deyimlerin çoklu ortam materyalleri kullanılarak öğretilmesi günümüzde yetişkin bireylerin bile zaman zaman anlamada güçlük çektikleri atasözleri ve deyimlerin çocuklara okul öncesi eğitim döneminde öğretilmeye başlanması gelecek açısından konuyla ilgili toplumsal ve kültürel değerlerin daha iyi anlaşılmasını ve aktarılmasına sunacağı katkı açısından da son derece önemli görülmektedir. Bununla birlikte okul öncesi eğitim döneminde atasözleri ve deyimlerin çoklu ortam materyalleri kullanılarak öğretilmesine yönelik olarak literatürde herhangi bir çalışmaya rastlanılmamıştır. Ayrıca bu çalışmanın, okul öncesi öğretmenlerine atasözleri ve deyimleri çoklu ortam materyalleri kullanarak çocuklara öğretmeleri konusunda dikkate değer bir rehber olacağı düşünülmektedir.

Bu araştırma, okul öncesi eğitim döneminde öğretmenlerin çocuklara atasözü ve deyimleri çoklu ortam materyallerini kullanarak öğretmesinin çocuklardaki konuyla ilgili öğrenme düzeylerini ne yönde etkileyeceğini belirlemeyi amaçlamaktadır. Bu amaç doğrultusunda aşağıdaki sorulara cevap aranmiştır:

1. Okul öncesi eğitim kurumlarına devam eden çocuklara atasözlerinin çoklu ortam materyalleri kullanılarak öğretilmesi onların atasözlerini anlama düzeylerini nasıl etkilemektedir?

2. Okul öncesi eğitim kurumlarına devam eden çocuklara deyimlerin çoklu ortam materyalleri kullanılarak öğretilmesi onların deyimleri anlama düzeylerini nasil etkilemektedir? 


\section{Yöntem}

Bu araştırma uygulamalı betimsel bir çalışmadır. Araştırma kapsamında nitel veri toplama yöntemlerinden biri olan odak grup görüşmesi yöntemi kullanılmıştır. Bu yöntemin veri toplama aracı olarak seçilmesinin nedeni atasözleri ve deyimler gibi okul öncesi eğitim döneminde çocukların anlamada zorlandıkları konuları çocuklara çoklu ortam materyallerini kullanarak öğretmek ve bu etkinlik sürecinin sonunda ortaya çıkan bulguları ve sonuçları çocuklara aynı sınıf ortamında birbirleriyle etkileşim ortamı sunan odak grup görüşmesi yöntemini kullanarak tespit etmektir. Bowling (2002)'e göre odak grup görüşmesi küçük bir grupla lider arasında yapılandırılmamış görüşme ve tartışmada grup dinamiğinin etkisini kullanma, derinlemesine bilgi edinme ve düşünce üretmedir. Krueger (1994) ise odak grup görüşmesini, bireylerin düşüncelerini serbestçe söyleyebileceği bir ortamda dikkatlice planlanmış bir tartışma olarak tanımlamaktadır. Öte yandan odak grup görüşmeleri, grupların, alt grupların, bilinçli, yarı bilinçli veya bilinçsiz olarak yaptıkları davranışlar ve psikolojik ve sosyokültürel özellikleri hakkında bilgi almayı, davranışlarının ardındaki nedenleri öğrenmeyi amaçlayan nitel bir yöntemdir (Akşit, 1992; Kroll, Barbour, ve Harris, 2007).

\section{Çalışma Grubu}

Bu araştırma 2019-2020 eğitim öğretim yılının ilk yarısında Erzurum il merkezinde okul öncesi eğitim kurumlarına devam eden 60-69 aylık yaş aralığına sahip 10 çocuğun katılımı ile gerçekleştirilmiştir. Çalışma grubu 5 kız (\%50) ve 5 erkek (\%50) çocuktan oluşmaktadır. Odak grup görüşmeleri için uygun katılımcı sayısı Kitzinger (1995)'e göre 4-9 kişi, Morgan (1997) ve Edmunds (2000)'a göre 8-10 kişidir. Bu sayı da genellikle 4 ile 10 kişi arasında değişmektedir (Çokluk, Yılmaz ve Oğuz, 2011). Odak grup görüşmesi yöntemi kullanılarak yapılan bu çalışmada çalışma grubu oluşturulurken amaçlı rastgele örnekleme yöntemi kullanılmıştır. Amaçlı rastgele örneklem sistematik ve rastgele seçilen durum örneklerinin araştırmanın amacı doğrultusunda amaçlı bir şekilde tasnif edilmesidir (Marshall \& Rossman, 2014). Araştırmacı öncelikle rasgele yöntemleri kullanarak evrenden bir örneklem grubu belirlemekte ve daha sonra bu grup içinden araştırmaya en çok katkı yapacağını düşündüğü küçük bir alt grubu seçmektedir (Tashakkori ve Teddlie, 2010). 
Bu doğrultuda bu araştırmada evrenden küçük bir örneklem grubu belirlenirken çocukların yaş aralıklarına (60-69 ay arası), kız ve erkek çocuk sayısının çalışma grubunda eşit sayıda temsil edilmesine, sosyoekonomik ve kültürel özelikleri gibi demografik özeliklerinin birbiriyle ayn veya benzer olmasına dikkat edilmiştir. Ayrıca çalışmaya katılacak olan çocukların ailelerine ve kendilerine araştırma süreciyle ilgili olarak bilgi verilmiş konuyla ilgili olarak çocuklarının çalışmaya katılmasına yönelik olarak ailelerin ve çocukların onayları alınmıştır. Bu süreç sonunda araştırmaya gönüllü olarak destek vermek isteyen çocuklarla araştırmaya devam edilmiştir.

\section{Verilerin Toplanması}

Araştırmanın verileri 2019-2020 eğitim öğretim yılının ilk yarısında okul öncesine devam eden çocuklarla yapılan toplam 90 dakika süren odak grup görüşmesi yardımıyla toplanmıştır. Yapılan odak grup görüşmesi yüz yüze eğitimin devam ettiği bir dönemde, Erzurum il merkezinde bulunan bir lisenin uygulama anaokuluna ait toplantı salonunda gerçekleştirilmiştir. Çalışma kapsamında çocuklara öğretmek amaciyla yapılacak odak grup görüşmesinin makul süresi göz önünde bulundurularak sekiz atasözü ve sekiz deyim belirlenmiştir. Bu atasözleri ve deyimler seçilirken Atasözleri ve Deyimler Sözlüğü 1-2 (Aksoy, 1988) kitaplarından yararlanılmıştır. Bu kitaplarda her atasözü ve deyim için bir numara verilmiş ve toplam sayı dikkate alındığında 50 'şer adet atasözü ve deyim elde edebilmek için rastgele (tesadüfi) olarak 53 artış miktarıyla atasözleri, 126 artış miktarıyla da deyimler belirlenmiştir. Atasözü ve deyimleri tesadüfi olarak belirleyebilmek için rastgele üretilen sayılarla 32. atasözünden ve 2794. deyimden başlanmıştır. Belirlenen bu atasözleri ve deyimlerden hangilerinin okul öncesi eğitim dönemindeki çocuklara sorulabileceği konusunda Türkçe öğretmenliği ana bilim dalı doktora unvanına sahip iki uzmanın görüşüne başvurulmuş, çocuklara sorulamayacak derecede soyut ve karmaşık olan atasözleri ve deyimler araştırma kapsamından çıkarılarak forma son şekli verilmiştir. Seçilen atasözü ve deyimler Tablo 1.'de de verilmektedir. 
Tablo 1. Etkinlik için seçilen atasözleri ve deyimler

\begin{tabular}{ll}
\hline Atasözleri & Deyimler \\
\hline Aç ayı oynamaz & Ağır söz \\
\hline Allah sağ eli sol ele muhtaç etmesin & Çil yavrusu gibi dağılmak \\
\hline Büyük balık küçük balı̆̆ıer & Dört duvar arasında \\
\hline Elmas çamura düşse yine elmas & Elinden hiçbir şey kurtulmamak \\
\hline Gülme komşuna gelir başına & Eski toprak \\
\hline Her kaşı̆̆ı kısmeti bir olmaz & Ĭğne atsan yere düşmez \\
\hline Öküze boynuzu yük olmaz & Sikboğaz etmek \\
\hline Yatan öküze yem yok & Sözünde durmak \\
\hline
\end{tabular}

Çalışma kapsamında çocuklara Tablo 1.'de sıralanan atasözü ve deyimlerden ne anladığı hazırlanan yapılandırılmış görüşme formu kullanılarak odak grup görüşmesi esnasında video izleme etkinliğinden önce sorulmuştur. Etkinlik aşamasında çocuklara içerisinde her bir atasözü ve deyimin ne anlama geldiğini ayrı ayrı anlatan çoklu ortam materyalleri kullanılarak hazırlanmış videolar izletilmiştir. Etkinlikten sonra bu atasözleri ve deyimlerden ne anladıklarına yönelik olarak hazırlanmış sorular içeren yapılandırılmış görüşme formu aracılığıyla yine çocuklarla odak grup görüşmesi yapılmış ve veriler toplanmıştır. Okul öncesi çağındaki çocuklar henüz okuma yazma bilmedikleri için yapılan etkinlik sonrasında, belirlenen atasözleri ve deyimlerin ne derece öğrenildiğini çocuklarla toplu bir şekilde görüşerek ölçülmesi planlanmıştır. Odak grup görüşmelerinde kaç kişinin konuyu öğrendiği değil, grubun tamamı analiz edilerek grup hakkındaki ölçümler ortaya koymak amaçlanmaktadır (Berg ve Lune, 2019).

Uyguma sürecine başlanmadan önce araştırmaya katılacak olan çocuklar, raportör ve moderatör için yaka kartı hazırlanmış, toplantı salonunda çocuklar için masalar ve oturma yerleri hazırlanmış, iki adet ses kayıt cihazı toplantısı salonunda hazır bulundurulmuş, çalışıp çalışmadıkları etkinlik öncesi kontrol edilmiştir. Yapılan bu odak grup görüşmelerine ait görüntüler etik kurallar gereği herhangi bir kamera kaydına alınmamıştır. Daha sonra görüşmenin yapılacağı yer, tarih ve saati katılımclara bir hafta öncesinden bildirilmiş, araştırmacılardan birisi moderatör diğeri ise raportör olarak belirlenen tarih ve saatte görüşme salonunda hazır bulunmuşlardır. Çocuklarla yapılacak olan odak grup görüşmesi öncesinde çocukların seslerinin kaydedileceği ancak herhangi bir kamera kaydı alınmayacağına dair aileler bilgilendirilmiş süreçle ilgili onayları alınmıştır. Ayrıca görüşmenin akışıyla ilgili çocuklara moderatör tarafından bilgi verilmiş, toplantının yapılacağı salonun kapısına 
davetsiz misafirlerin girişini engellemek için bir uyarı yazısı konmuş, bu esnada çalışma grubunda yer alan tüm çocukların yerlerini alması beklenmiş, grup tamamlandığında moderatör görüşmelerin ses kayıtlarının alınacağını çalışma grubunda yer alan çocuklara açıklamıştır. Yapılan bu araştırma sürecinin araştırmacılar tarafından raporlaştırılacağı, ses kayıtlarının ve çocukların isimlerinin kimseyle paylaşılmayacağ yer alan çocukların ailelere gerekli bilgilendirmeler yapılmıştır. Ayrıca görüşmeye başlamadan önce moderatör ve raportöre ait cep telefonları kapatılmış ve görüşme sürecine geçilmiştir. Görüşme sürecinde çalışma grubunda yer alanlar çocuk oldukları için her yarım saatte bir 15 dakikalık iki ara verilmiş verilen bu aralar görüşme süresi içerisine dâhil edilmemiştir. Görüşme sürecine moderatör tarafından çocuklara televizyonla, telefonla ve bilgisayarlarla aranız nasıl bunlardan çizgi film izlemeyi seviyor musunuz şeklinde onların dikkatini çekmeye yönelik bir soruyla başlanmıştır. Daha sonra görüşme sürecine geçilmiş ve araştırmacılar tarafından etkinlik öncesinde hazırlanan ve içerisinde görüşme sorularının yer aldığı atasözü ve deyimlerden oluşan sorular, çocuklara bir sohbet ortamı içerisinde sorulmaya başlanmıştır. Çocukların sorulara verdikleri yanıtlar doğrultusunda "çok iyi anladı, anladı, kısmen anladı, hiç anlamadı" şeklinde bu formda yer alan kutucuklara işaretler konarak kendilerine sorulan atasözleri ve deyimler konusunda başlangıçta ne düzeyde bilgi sahibi oldukları ölçülmeye çalışılmıştır. Etkinlik sonrasında ise çocuklara her biri ayrı ayrı olarak ortalama 2 dakika süren çoklu ortam materyalleri şeklinde hazırlamış videolar izlettirilmiş ve çocukların videoları izledikten sonra ulaştıkları öğrenme düzeylerini ölçmek amacıyla yine aynı form kullanılarak gerekli işaretlemeler yapılmıştır.

\section{Verilerin Analizi}

Odak grup görüşmeleri esnasında kullanılan yapılandırılmış görüşme formları ile toplanan veriler içerik analizi yöntemi ile analiz edilmiştir. İçerik analizinde belirli bir konu üzerinde yapılan çalışmalar ele alınarak bu çalışmaların eğilimleri ve sonuçları tanımlayıcı ve sistematik bir biçimde değerlendirilir (Lin, Lin, \& Tsai, 2014). İçerik analizinde temelde yapılan işlem, birbirine benzeyen verileri belirli kavramlar ve temalar çerçevesinde bir araya getirmek ve bunları okuyucunun anlayabileceği bir biçimde düzenleyerek yorumlamaktır (Yıldırım ve Şimşek, 2005). Bu kapsamda raportör tarafından 
her bir katılımcı çocuk için ayrı ayrı işaretlenen formlar incelenmiş ve sonuçlar karşılaştıılmıştır. Herhangi bir atasözü veya deyim üzerinde yapılan farklı işaretlemeler görüşmelerin ses kayıtları yeniden dinlenmek suretiyle tartışılmış ve araştırmacılar tarafından görüş birliğine varıldıktan sonra değerlendirme kapsamına alınmıştır.

\section{Bulgular}

Araştırma kapsamında odak grup görüşmesine katılan çocuklara atasözü ve deyimlerin çoklu ortam materyalleriyle öğretilmesine yönelik bir etkinlik yapılmıştır. Etkinlik öncesinde ve sonrasında çocukların belirlenen atasözleri ve deyimleri ne derece bildiklerini ölçmek amacıyla sorular sorulmuş ve çocuklar "Hiç anlamadı, kısmen anladı, anladı ve çok iyi anladı" şeklinde sınıflandırılmıştır. Çalışmanın bulgularının anlaşılmasını kolaylaştırmak için araştırmada kullanılan atasözleri ve deyimlere ilişkin çocukların etkinlik öncesi ve sonrası verdikleri cevaplar tablo halinde verilmiş, bu atasözleri ve deyimlere ait bulgular sonrasında karşılaştırmalı olarak açıklanmıştır.

\section{Etkinlik Öncesi ve Sonrası Atasözlerinin Anlaşılma Düzeyine İlişkin Bulgular}

Genel olarak çocukların etkinlik öncesinde kendilerine öğretilmeye çalışılan atasözlerinin ne anlama geldiğini çok iyi olarak bilmedikleri görülmüştür. Çoklu ortam materyalleri kullanılarak yapılan etkinlik sonrasında ise atasözlerinin ise ne anlama geldiği, başta "Allah sağ eli sol ele muhtaç etmesin", "Büyük balık küçük balığı yer”, "Gülme komşuna gelir başına”, “Öküze boynuzu yük olmaz" ve "Yatan öküze yem yok" atasözleri olmak üzere, çocuklar tarafından kısmen veya çeşitli derecelerde anlaşıldığı tespit edilmiştir.

Etkinlik öncesi ve sonrası çocukların her bir atasözüne yönelik anlama düzeyleri Tablo 2.'de verilmektedir. 
Tablo 2. Atasözlerine ait bulguları etkinlik öncesi ve sonrası dağılımı

\begin{tabular}{|c|c|c|c|c|c|c|c|c|}
\hline \multirow[b]{2}{*}{ Atasözleri } & \multicolumn{3}{|c|}{ Etkinlik Öncesi } & \multicolumn{5}{|c|}{ Etkinlik Sonrası } \\
\hline & 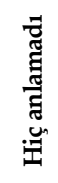 & 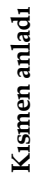 & $\frac{\tilde{\sigma}}{\tilde{z}}$ & 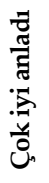 & 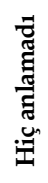 & 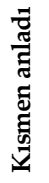 & $\frac{\tilde{\pi}}{\tilde{Z}}$ & 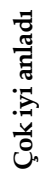 \\
\hline Aç ayı oynamaz & 6 & 3 & 1 & - & - & 1 & 6 & 3 \\
\hline Allah sağ eli sol ele muhtaç etmesin & 9 & 1 & - & - & 2 & 1 & 2 & 5 \\
\hline Büyük balık küçük balığı yer & 3 & 5 & 2 & - & - & 2 & 4 & 4 \\
\hline Elmas çamura düşse yine elmas & 7 & 2 & 1 & - & 4 & 3 & 2 & 1 \\
\hline Gülme komşuna gelir başına & 3 & 4 & 3 & - & - & 1 & 3 & 6 \\
\hline Her kaşığın kısmeti bir olmaz & 10 & - & - & - & 4 & 1 & 2 & 3 \\
\hline Öküze boynuzu yük olmaz & 8 & 2 & - & - & 1 & 2 & 2 & 5 \\
\hline Yatan öküze yem yok & 4 & 2 & 4 & - & - & 1 & 3 & 6 \\
\hline Toplam & 50 & 19 & 11 & - & 11 & 12 & 24 & 33 \\
\hline
\end{tabular}

Aç Ayı Oynamaz Atasözüne İlişkin Bulgular: Odak grup görüşmesine katılan çocukların "Aç ayı oynamaz" atasözüyle ilgili etkinlik öncesi ve sonrası görüşleri şu şekilde açıklanabilir: Görüşmeye katılan çocukların çoğunluğu (f:6) aç ayı oynamaz atasözünden etkinlik öncesi hiçbir şey anlamadıklarını ifade ederken, (f:3) kısmen anladıkları ve (f:1) anladığını ifade etmiştir. Görüşmeye katılan çocuklara çoklu ortam materyalleri kullanılarak "Aç ayı oynamaz" konusuyla ilgili hazırlanan video uygulaması izletildikten sonra çocukların çoğunun aç ayı oynamaz atasözünü (f:6) anladığını, (f:3) çok iyi anladıklarını (f:1) kısmen anladığını ifade ettikleri belirlenmiştir. Ayrıca odak grup görüşmesine katılan çocuklardan etkinlik öncesinde aç ayı oynamaz atasözünü çok iyi anlayan öğrencinin olmaması ve etkinlik sonrasında yapılan çoklu ortam tasarımları kullanılarak hazırlanmış video çocuklara izlettirildikten sonrada hiç anlamayan çocuğun kalmaması dikkat çekici bir bulgu olarak karşımıza çıkmaktadır.

Allah să̆ eli sol ele muhtaç etmesin atasözüne ilişkin bulgular: Odak grup görüşmesine katılan çocukların "Allah sağ eli sol ele muhtaç etmesin" atasözüyle ilgili etkinlik öncesi ve sonrası görüşleri şu şekilde açıklanabilir: Görüşmeye katılan çocukların büyük çoğunluğu (f:9) “Allah sağ eli sol ele muhtaç etmesin" atasözünden etkinlik öncesi hiçbir şey anlamadıklarını ifade ederken, (f:1) kısmen anladığını ifade etmiştir. Görüşmeye katılan çocuklara çoklu ortam materyalleri kullanılarak hazırlanmış "Allah sağ eli sol ele muhtaç et- 
mesin" atasözüyle ilgili video uygulaması izletildikten sonra çocukların çoğunun "Allah sağ eli sol ele muhtaç etmesin" atasözünü (f:5) çok iyi anladıklarını, (f:2) anladıklarını, (f:2) hiç anlamadıklarını, (f:1) kısmen anladığını ifade belirtmiştir. Bununla birlikte odak grup görüşmesine katılan çocukların etkinlik öncesinde "Allah sağ eli sol ele muhtaç etmesin" atasözünü anlayan veya çok iyi anlayan herhangi bir çocuğun olmaması dikkat çekici bir bulgu olarak değerlendirilebilir.

Büyük Balık Küçük Balığı Yer Atasözüne İlişkin Bulgular: Odak grup görüşmesine katılan çocukların "Büyük balık küçük balığı yer" atasözüyle ilgili etkinlik öncesi ve sonrası görüşleri şu şekilde açıklanabilir: Görüşmeye katılan çocukların "Büyük balık küçük balığı yer" atasözünden etkinlik öncesi (f:5) kısmen anladıklarını ifade ederken, (f:3) hiçbir şey anlamadıklarını, (f:2) anladıklarını ifade etmişlerdir. Görüşmeye katılan çocuklara çoklu ortam materyalleri kullanılarak hazırlanmış “Büyük balık küçük balığı yer” atasözüyle ilgili video uygulaması izletildikten sonra çocukların çoğunun "Büyük balık küçük balığı yer" atasözünü (f:4) çok iyi anladıklarını, (f:4) anladıklarını, (f:2) kısmen anladıklarını ifade etmişlerdir. Öte yandan odak grup görüşmesine katılan çocukların etkinlik öncesinde "Büyük balık küçük balığı yer " atasözünden çok iyi anlayan çocuğun olmaması etkinlik sonrasında ise hiç anlamayan çocuğun kalmaması ilgi çekici bir bulgu olarak karşımıza çıkmaktadir.

Elmas Çamura Düşse Yine Elmas Atasözüne İlişkin Bulgular: Odak grup görüşmesine katılan çocukların "Elmas çamura düşse yine elmas" atasözüyle ilgili etkinlik öncesi ve sonrası görüşleri şu şekilde açıklanabilir: Görüşmeye katılan çocukların etkinlik öncesi "Elmas çamura düşse yine elmas" atasözünden büyük çoğunluğunun (f:7) hiç anlamadıklarını ifade ederken, (f:2) kısmen anladıklarını, (f:1) anladığını ifade etmişlerdir. Görüşmeye katılan çocuklara çoklu ortam materyalleri kullanılarak hazırlanmış "Elmas çamura düşse yine elmas" atasözüyle ilgili video uygulaması izletildikten sonra çocukların çoğunun "Elmas çamura düşse yine elmas" atasözünü (f:4) hiç anlamadıklarını (f:3) kısmen anladıklarını, (f:2) anladıklarını ve (f:1) çok iyi anladığını ifade etmiştir. Odak grup görüşmesine katılan çocukların etkinlik ön- 
cesinde "Elmas çamura düşse yine elmas" atasözünden çok iyi anlayan çocuğun olmadığı, etkinlik sonrasında ise hala hiç anlamayan çocukların sayısının fazla olduğu tespit edilmiştir.

Gülme Komşuna Gelir Başına Atasözüne İlişkin Bulgular: Odak grup görüşmesine katılan çocukların “Gülme komşuna gelir başına” atasözüyle ilgili etkinlik öncesi ve sonrası görüşleri şu şekilde açıklanabilir: Görüşmeye katılan çocukların (f:4) "Gülme komşuna gelir başına” atasözünü etkinlik öncesi kısmen anladıklarını ifade ederken, (f:3) anladıklarını ve (f:3) hiç anlamadıklarını ifade etmişlerdir. Görüşmeye katılan çocuklara çoklu ortam materyalleri kullanılarak hazırlanmış "Gülme komşuna gelir başına" atasözüyle ilgili video uygulaması izletildikten sonra çocukların çoğunun "Gülme komşuna gelir başına " atasözünü (f:6) çok iyi anladıklarını (f:3) anladıklarını, (f:1) kısmen anladığını ifade ettiği belirlenmiştir. Bununla birlikte odak grup görüşmesine katılan çocuklardan etkinlik öncesinde "Gülme komşuna gelir başına" atasözünü çok iyi anlayan herhangi bir çocuğun olmayışı ve etkinlik sonrasında bu atasözünü hiç anlamayan çocuğun kalmaması kayda değer bir bulgu olarak karşımıza çıkmaktadır.

Her Kaşığın Kısmeti Bir Olmaz Atasözüne İlişkin Bulgular: Odak grup görüşmesine katılan çocukların "Her kaşığın kısmeti bir olmaz" atasözüyle ilgili etkinlik öncesi ve sonrası görüşleri şu şekilde açılanabilir: Görüşmeye katılan çocukların tamamı (f:10) "Her kaşı̆̆ın kısmeti bir olmaz" atasözünden etkinlik öncesi hiç anlamadıklarını ifade etmişlerdir. Görüşmeye katılan çocuklara çoklu ortam materyalleri kullanılarak hazırlanmış "Her kaşığın kısmeti bir olmaz" atasözüyle ilgili video uygulaması izletildikten sonra çocukların çoğunun "Her kaşığın kısmeti bir olmaz" atasözünü (f:4) hiç anlamadıklarını, (f:3) çok iyi anladıklarını, (f:2) anladıklarını, (f:1) kısmen anladığını ifade etmiştir. Bununla birlikte odak grup görüşmesine katılan çocuklardan etkinlik öncesinde tamamının; etkinlik sonrası ise çoğunun "Her kaşı̆̆ın kısmeti bir olmaz" atasözünü hiç anlamamaları önemli bir bulgu olarak tespit edilmiştir.

Öküze Boynuzu Yük Değil Atasözüne İlişkin Bulgular: Odak grup görüşmesine katılan çocukların "Öküze boynuzu yük değil " atasözüyle ilgili etkinlik öncesi ve sonrası görüşleri şu şekilde açıklanabilir: Görüşmeye katılan çocukların büyük çoğunluğunun (f:8) “Öküze boynuzu yük değil” atasözünü etkinlik öncesi hiç anlamadıkları, (f:2) kısmen anladıklarını ifade etmişlerdir. 
Görüşmeye katılan çocuklara çoklu ortam materyalleri kullanılarak hazırlanmış "Öküze boynuzu yük değil" atasözüyle ilgili video uygulaması izletildikten sonra çocukların çoğunun “Öküze boynuzu yük değil” atasözünü (f:5) çok iyi anladıklarını (f:2) anladıklarını, (f:2) kısmen anladıklarını ve (f:1) hiç anlamadığını ifade etmiştir. Bununla birlikte odak grup görüşmesine katılan çocuklardan etkinlik öncesinde "Öküze boynuzu yük olmaz " atasözünü anlayan veya çok iyi anlayan herhangi bir çocuğun olmayışı ve etkinlik sonrasında ise çocukların çoğunun atasözünü çok iyi anlamaları dikkat çekici bir bulgu olarak karşımıza çıkmaktadır.

Yatan Öküze Yem Yok Atasözüne İlişkin Bulgular: Odak grup görüşmesine katılan çocukların "Yatan öküze yem yok " atasözüyle ilgili etkinlik öncesi ve sonrası görüşleri şu şekilde açıklanabilir: Görüşmeye katılan çocukların (f:4) "Yatan öküze yem yok" atasözünü etkinlik öncesi hiç anlamadıkları, (f:4) anladıklarını ve (f:2) kısmen anladıklarını ifade etmişlerdir. Görüşmeye katılan çocuklara çoklu ortam materyalleri kullanılarak hazırlanmış "Yatan öküze yem yok" atasözüyle ilgili video uygulaması izletildikten sonra çocukların çoğunun "Yatan öküze yem yok" atasözünü (f:6) çok iyi anladıklarını (f:3) anladıklarını, (f:1) kısmen anladıklarını ifade ettikleri belirlenmiştir.

\section{Etkinlik Öncesi ve Sonrası Deyimlere İlişkin Bulgular}

Genel olarak çocukların etkinlik öncesinde kendilerine öğretilmeye çalışılan deyimlerin ne anlama geldiğini çok iyi olarak bilmedikleri görülmüştür. Çoklu ortam materyalleri kullanılarak yapılan etkinlik sonrasında ise deyimlerin ne anlama geldiği, başta "Sözünde durmak", "Elinden hiçbir şey kurtulmamak" ve "Iğne atsan yere düşmez" deyimleri olmak üzere, çocuklar tarafından kısmen veya çeşitli derecelerde anlaşıldığı tespit edilmiştir.

Etkinlik öncesi ve sonrası çocukların her bir deyime yönelik anlama düzeyleri Tablo 3.'te verilmektedir. 
Tablo 3. Deyimlere ait bulgularn etkinlik öncesi ve sonrası dağılımı

\begin{tabular}{|c|c|c|c|c|c|c|c|c|}
\hline \multirow[b]{2}{*}{ Deyimler } & \multicolumn{3}{|c|}{ Etkinlik Öncesi } & \multicolumn{5}{|c|}{ Etkinlik Sonrası } \\
\hline & 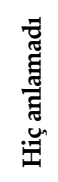 & 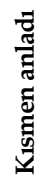 & $\frac{\tilde{\sigma}}{\tilde{Z}}$ & 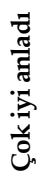 & 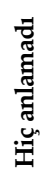 & 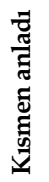 & $\frac{\bar{Z}}{\tilde{Z}}$ & 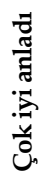 \\
\hline Ağır söz & 7 & 1 & 2 & - & 2 & 1 & 5 & 2 \\
\hline Çil yavrusu gibi dağılmak & 7 & 2 & 1 & - & 2 & 4 & 3 & 1 \\
\hline Dört duvar arasında & 3 & 4 & 3 & - & - & 3 & 4 & 3 \\
\hline Elinden hiçbir şey kurtulmamak & 6 & 2 & 2 & - & 2 & 1 & 3 & 4 \\
\hline Eski toprak & 5 & 4 & 1 & - & 3 & - & 4 & 3 \\
\hline İğne atsan yere düşmez & 7 & - & 3 & - & 1 & 1 & 4 & 4 \\
\hline Sıkboğaz etmek & 6 & 1 & 3 & - & 3 & 3 & 2 & 2 \\
\hline Sözünde durmak & 4 & - & 6 & - & - & 1 & 3 & 6 \\
\hline Toplam & 45 & 14 & 21 & - & 13 & 14 & 28 & 25 \\
\hline
\end{tabular}

Ağır söz deyimine ilişkin bulgular: Odak grup görüşmesine katılan çocukların "Ağır söz" deyimiyle ilgili etkinlik öncesi ve sonrası görüşleri şu şekilde açılanabilir: Görüşmeye katılan çocukların büyük çoğunluğu (f:7), "Ağır söz" deyiminden etkinlik öncesi hiç anlamadıklarını ifade ederken, (f:2) anladıkları ve (f:1) kısmen anladığını ifade etmiştir. Görüşmeye katılan çocuklara çoklu ortam materyalleri kullanılarak hazırlanmış "Ağır söz" deyimiyle ilgili video uygulaması izletildikten sonra çocukların çoğunun" Ağır söz" deyimini (f:5) anladığını, (f:2) çok iyi anladıklarını, (f:2) hiç anlamadıklarını ve (f:1) kısmen anladığını ifade etmiştir.

Çil yavrusu gibi dağılmak deyimine ilişkin bulgular: Odak grup görüşmesine katılan çocukların "Çil yavrusu gibi dağılmak" deyimiyle ilgili etkinlik öncesi ve sonrası görüşleri şu şekilde açıklanabilir: Görüşmeye katılan çocukların büyük çoğunluğu (f:7), “Çil yavrusu gibi dağılmak” deyiminden etkinlik öncesi hiç anlamadıklarını ifade ederken, (f:2) kısmen anladıkları ve (f:1) anladığını ifade etmiştir. Görüşmeye katılan çocuklara çoklu ortam materyalleri kullanılarak hazırlanmış “Çil yavrusu gibi dağılmak” deyimiyle ilgili video uygulaması izletildikten sonra çocukların çoğunun" Çil yavrusu gibi dağılmak" deyimini çoğunlukla (f:4) kısmen anladıklarını, (f:3) anladıklarını, (f:2) hiç anlamadıklarını, (f:1) çok iyi anladıklarını ifade etmişlerdir. 
Dört duvar arasında deyimine ilişkin bulgular: Odak grup görüşmesine katılan çocukların "Dört duvar arasında" deyimiyle ilgili etkinlik öncesi ve sonrası görüşleri şu şekilde açıklanabilir: Görüşmeye katılan çocukların (f:4), "Dört duvar arasında" deyiminden etkinlik öncesi kısmen anladıklarını ifade ederken, (f:3) anladıklarını, (f:3) hiç anlamadıklarını ifade etmişlerdir. Görüşmeye katılan çocuklara çoklu ortam materyalleri kullanılarak hazırlanmış "Dört duvar arasında" deyimiyle ilgili video uygulaması izletildikten sonra çocukların" Dört duvar arasında" deyimini çoğunlukla (f:4) anladıkları, (f:3) çok iyi anladıkları, (f:3) kısmen anladıklarını ifade etmişlerdir. Bununla birlikte etkinlik öncesinde odak grup görüşmesine katılan çocukların “Dört duvar arasında" deyiminden çok iyi anlayan herhangi bir çocuk olmadığı belirlenmiş, etkinlik sonrasında ise "Dört duvar arasında" deyiminden çocukların çoğunun anladıkları belirlenmiştir.

Elinden hiçbir şey kurtulmamak deyimine ilişkin bulgular: Odak grup görüşmesine katılan çocukların "Elinden hiçbir şey kurtulmamak" deyimiyle ilgili etkinlik öncesi ve sonrası görüşleri şu şekilde açıklanabilir: Görüşmeye katılan çocukların çoğunluğu (f:6), "Elinden hiçbir şey kurtulmamak" deyiminden etkinlik öncesi hiç anlamadıklarını ifade ederken, (f:2) anladıklarını, (f:2) anladıklarını ifade etmişlerdir. Görüşmeye katılan çocuklara çoklu ortam materyalleri kullanılarak hazırlanmış "Elinden hiçbir şey kurtulmamak" deyimiyle ilgili video uygulaması izletildikten sonra çocukların "Elinden hiçbir şey kurtulmamak" deyimini çoğunlukla (f:4) çok iyi anladıkları, (f:3) anladıkları, (f:2) hiç anlamadıklarını, (f:1) kısmen anladığını ifade etmişlerdir.

Eski toprak deyimine ilişkin bulgular: Odak grup görüşmesine katılan çocukların "Eski toprak" deyimiyle ilgili etkinlik öncesi ve sonrası görüşleri şu şekilde açıklanabilir: Görüşmeye katılan çocukların çoğunluğu (f:5), "Eski toprak" deyiminden etkinlik öncesi hiç anlamadıklarını ifade ederken, (f:4) kısmen anladıklarını, (f:1) anladığını ifade etmişlerdir. Görüşmeye katılan çocuklara çoklu ortam materyalleri kullanılarak hazırlanmış "Eski toprak" deyimiyle ilgili video uygulaması izletildikten sonra çocukların "Eski toprak" deyimini çoğunlukla (f:4) anladıkları, (f:3) anladıkları, (f:3) çok iyi anladıklarını, (f:3) hiç anlamadıklarını ifade etmişlerdir. 
İğne atsan yere düşmez deyimine ilişkin bulgular: Odak grup görüşmesine katılan çocukların "İ̆gne atsan yere düşmez" deyimiyle ilgili etkinlik öncesi ve sonrası görüşleri şu şekilde açiklanabilir: Görüşmeye katılan çocukların büyük çoğunluğu (f:7), “Iğne atsan yere düşmez” deyiminden etkinlik öncesi hiç anlamadıklarını ifade ederken, (f:3) anladıklarını ifade etmişlerdir. Görüşmeye katılan çocuklara çoklu ortam materyalleri kullanılarak hazırlanmış "İgne atsan yere düşmez" deyimiyle ilgili video uygulaması izletildikten sonra çocukların "Iğne atsan yere düşmez" deyimini çoğunlukla (f:4) çok iyi anladıkları, (f:4) anladıkları, (f:1) kısmen anladığını, (f:1) hiç anlamadığını ifade etmiştir.

Sikboğaz etmek deyimine ilişkin bulgular: Odak grup görüşmesine katılan çocukların "Sıkboğaz etmek" deyimiyle ilgili etkinlik öncesi ve sonrası görüşleri şu şekilde açıklanabilir: Görüşmeye katılan çocukların çoğunluğu (f:6), "Sıkboğaz etmek" deyiminden etkinlik öncesi hiç anlamadıklarını ifade ederken, (f:3) anladıklarını, (f:1) kısmen anladığını ifade etmiştir. Görüşmeye katılan çocuklara çoklu ortam materyalleri kullanılarak hazırlanmış "Sıkboğaz etmek" deyimiyle ilgili video uygulaması izletildikten sonra çocukların "Sıkboğaz etmek" deyimini çoğunlukla (f:3) kısmen anladıkları, (f:3) hiç anlamadıklarını, (f:2) çok iyi anladığını, (f:2) anladıklarını ifade etmiştir.

Sözünde durmak deyimine ilişkin bulgular: Odak grup görüşmesine katılan çocukların "Sözünde durmak" deyimiyle ilgili etkinlik öncesi ve sonrası görüşleri şu şekilde açıklanabilir: Görüşmeye katılan çocukların çoğunluğu (f:6), "Sözünde durmak" deyiminden etkinlik öncesi anladığını ifade ederken, (f:4) hiç anlamadığını, ifade etmiştir. Görüşmeye katılan çocuklara çoklu ortam materyalleri kullanılarak hazırlanmış "Sözünde durmak" deyimiyle ilgili video uygulaması izletildikten sonra çocukların "Sözünde durmak" deyimini çoğunlukla (f:6) çok iyi anladıklarını, (f:3)anladıklarını, (f:1) kısmen anladığını, ifade etmiştir. Ayrıca etkinlik öncesinde odak grup görüşmesi yapılan çocukların "Sözünde durmak" deyiminden çok iyi anlayan herhangi bir çocuğun olmadığı, etkinlik sonrasında ise "Sözünde durmak" deyiminden çocukların çoğunun çok iyi anladıkları tespit edilmiştir. 


\section{Tartışma, Sonuç ve Öneriler}

Bu çalışma, okul öncesi eğitim döneminde çocuklara atasözü ve deyimleri öğretmede öğretmenlerin çoklu ortam materyallerinden yararlanmasının çocuklardaki atasözü ve deyimlerle ilgili öğrenme düzeylerini ne yönde etkileyeceğini belirlemeyi amaçlamaktadır. Bu kapsamda araştırmadan elde edilen bulgulara dayanarak çalışmaya katılan okul öncesi eğitim kurumlarına devam eden çocukların çoğunun etkinlik öncesinde kendilerine sorulan atasözlerin genel olarak ne anlama geldiğini hiç anlamadıkları, yine etkinlik öncesinde kendilerine sorulan herhangi bir atasözünden çok iyi anlayan çocuğun olmadığı sonucuna ulaşılmıştır. Bununla birlikte çalışma grubunda yer alan çocuklara yönelik olarak çoklu ortam materyalleri kullanılarak her bir atasözü için ayrı ayrı olarak hazırlanmış onların dikkat ve ilgisini çekecek atasözleriyle ilgili videolar izlettirilmiş ve daha sonra bu atasözlerinin ne anlama geldikleri kendilerine sorulmuş ve çoğunlukla çok iyi anladıkları sonucuna ulaşılmıştır. Alanyazında çoklu ortam materyali kullanımının ilkokul (Çoruk ve Çakır, 2017), ortaokul (Yanmaz ve Bozdoğan, 2016) ve lise (Kert ve Tekdal, 2018) düzeyindeki başarıya etki ettiğine dair çalışmalara rastalamak mümkündür. Bu çalışma ile okul öncesi düzeyde de çoklu ortam ile yapılan somutlaştırmanın atasözleri ve deyimlerin öğretilmesine katkı sağladığı sonucuna varılmıştır. Ancak yapılan etkinlik çalışmasının sonucunda "Aç ayı oynamaz", "Büyük balık küu̧ük balığı yer", "Gülme komşuna gelir başına” ve "Yatan öküze yem yok" atasözünden hala hiç anlamayan çocukların olduğu belirlenmiştir.

Ayrıca çalışma grubunda yer alan çocukların etkinlik öncesinde kendilerine sorulan deyimlerin ne anlama geldiğine ilişkin olarak etkinlik öncesinde bu deyimlerin anlamların çoğunlukla hiç bilmediklerini yine etkinlik öncesinde kendilerine sorulan herhangi bir deyimin ne anlama geldiğini çok iyi anlayan çocuğun olmadığı belirlenmiştir. Öte yandan çalışma grubunda yer alan çocuklara yönelik olarak çoklu ortam materyalleri kullanılarak her bir deyim için ayrı ayrı olarak hazırlanmış olan onların dikkat ve ilgisini çekecek deyimlerle ilgili videolar izlettirilmiş ve daha sonra bu deyimlerin ne anlama geldikleri kendilerine sorulmuş ve çoğunlukla anladıkları sonucuna ulaşılmıştır. Ancak yapılan etkinlik çalışmasının sonucunda da "Dört duvar arasında" ve "Sözünde durmak" deyimlerinden hala hiç anlamayan çocukların 
olduğu tespit edilmiştir. Deyimlerde de atasözleri gibi gerçek anlamın d1şında mecazî anlam söz konusudur. Anonim olma vasfı taşıyan deyimlerle atasözleri birlikte bir bütünlük oluştururlar (Bulut, 2013). Arslan, Dönmez, Davarcıoğlu, Eren ve Aytar (2019), yaptıkları araştırmada okul öncesi dönem çocuklarının bilişsel gelişim olarak işlem öncesi evrede oldukları için soyut kavramları algılamakta güçlük çektiklerini, bu dönemde çocukların atasözleri ve deyimleri, benzetmeleri ve mecaz sözcükleri gerçek anlamlarıyla alg1ladıklarını belirtmişlerdir.

Araştırma sonuçlarından da anlaşılacağı gibi atasözleri ve deyimlerin okul öncesi eğitim döneminde çocuklara öğretmenler tarafından çoklu ortam materyalleri kullanılarak öğretilmesi onların atasözleri ve deyimleri daha iyi anlamalarını sağladığı ve öğrenmelerini kolaylaştırdığı görülmektedir. Preradović, Unić ve Boras (2014), çocukların çok erken yaşlarda çoklu ortam okuryazarlığı becerisi kazandıklarını ileri sürmüşlerdir. Bu becerilerini kullanarak okul öncesi eğitimlerde çoklu ortam kullanımının yaygınlaştırılması önerilebilir. Mobil ve multimedya, bu kritik yaş için bilgi ve deneyimleri geliştirebilecek araçlar olarak kabul edilmektedir ve anaokulundaki belirli alanların eğitim perspektifine göre desteklenmesinin önemli olduğu düşünülmektedir (Drigas, Kokkalia, ve Lytras, 2015).

Çocukların etkinlik öncesinde ve sonrasında hiç anlamadıkları atasözleri ve deyimlerin olması onların içinde bulundukları yaş ve dil gelişim seviyeleriyle ilgili olduğu düşünülmektedir. Bu araştırma sonuçlarından hareketle şu öneriler getirilebilir:

- Atasözleri ve deyimlerin öğretilmesine yönelik çalışmalara okul öncesi, ilkokul ve ortaokul programlarında yer verildiği görülmektedir. Bu nedenle özelikle okul öncesi eğitim döneminde çocuklara atasözleri ve deyimlerin çoklu ortam materyalleri kullanılarak öğretilmesi, öğrenme sürecini çok daha zevkli ve eğlenceli hale getirebilir.

- Özellikle okul öncesi eğitim programlarında çocukların dil gelişimine katkıda bulunmak için öğretilmesi planlanan etkinliklerde geçen atasözleri ve deyimler seçilirken daha kolay ve anlaşılır atasözleri ve deyimlerin seçilerek öğretilmeye başlanması çocukların içinde bulundukları yaş ve gelişim düzeyleri açısından daha doğru bir yaklaşım olabilir.

- Okul öncesi eğitim döneminde, çocuklara atasözleri ve deyimlerin anlamlarının birbirinden bağımsız konularmış gibi değil de, birbirini ta- 
mamlayan konularmış gibi bir bütün olarak, birlikte çoklu ortam materyalleriyle zenginleştirilerek öğretilmesi, öğrenme sürecini daha somut hale getirebilir.

- Okul öncesi eğitim döneminde çocuklara atasözleri ve deyimlerin anlamlarının öğretilmesi sadece öğretmenlerin işi olmamalı aynı zamanda ailelerinde konuyla ilgili etkin rol almaları öğrenme sürecini daha dinamik hale getirebilir. 


\title{
EXTENDED ABSTRACT
}

\section{The Effect of Embodying Proverbs and Idioms with Multimedia Materials on Preschool Education}

\author{
Abdullatif Kaban - Ayhan Bulut \\ Bayburt University
}

Language is one of the most important building blocks of the culture that emerged with the existence of humanity and enables societies to understand and communicate with each other between the past and the present. There are proverbs and idioms bearing traces of the cultural textures of each society that find meaning in its own language. Making use of multimedia materials to teach children proverbs and idioms in preschool education in a way that will attract the attention and attention of children will make the content of the education to be given to children richer and more qualified. In its simplest sense, multimedia is environments that appeal to the eyes, ears, and sense of touch. There has been no study in the literature regarding the teaching of proverbs and idioms using multimedia materials in the pre-school education period. Besides, this study is thought to be a remarkable guide to preschool teachers to teach proverbs and idioms using multimedia materials. The method used in this study is important in that it allows an easier understanding of language and music activities in preschool education programs.

This study aims to determine how teachers' teaching proverbs and idioms to children using multimedia materials in the pre-school education period will affect their learning levels in children. For this purpose, the following questions were sought:

1. How does teaching proverbs to children attending pre-school education institutions using multimedia materials affect their level of understanding proverbs?

2. How does teaching idioms to children attending pre-school education institutions using multimedia materials affect their understanding of idioms? 
This research is an applied descriptive study. The focus group interview method, one of the qualitative data collection methods, was used within the scope of the research. This research was carried out in Erzurum city center with the participation of 10 children, who are in the 60-69 month age range, who attend preschool education institutions in the first half of the 2019-2020 academic year. Within the scope of the study, the data were collected through focus group discussion. In the focus group meeting, an event was made by showing the multimedia videos about the proverbs and idioms to the children. During the interview, a structured interview form with questions consisting of eight proverbs and eight idioms was used as the data collection tool. What they understood from these proverbs and idioms were measured by the questions asked to the children before and after the activity. The data of proverbs and idioms included in the research were examined in separate titles. Content analysis method was used to analyze the data.

Based on the findings obtained from the study, it was concluded that most of the children attending pre-school education institutions participating in the study did not understand what the proverbs they were asked before the event meant in general and that there were no children who understood very well any proverbs asked before the event. Besides, the children in the study group were made to watch videos prepared separately for each proverb, and then they were asked what these proverbs mean and it was concluded that they mostly understood very well.

With the questions about the meaning of the idioms asked them before the activity, it was determined that the children in the study group did not understand the meaning of any idiom very well. On the other hand, the children in the study group were made to watch videos prepared separately for each idiom, and then they were asked what these idioms mean and it was concluded that they mostly understood. With this study, it was concluded that concretization made with multimedia at the preschool level contributes to the teaching of proverbs and idioms. Based on these research results, the following suggestions can be made:

- Especially during pre-school education, teaching children proverbs and idioms using multimedia materials can make the learning process much more enjoyable and enjoyable. 
- While choosing proverbs and idioms that are planned to be taught in preschool education programs, choosing from easier and more understandable ones may be a better approach in terms of the age and development levels of children.

- In the pre-school education period, teaching children proverbs and idioms as if they are not independent subjects, but as complementary subjects, and enriched with multimedia materials together, can make the learning process more concrete.

- Teaching the meanings of proverbs and idioms to children in the preschool education period should not only be the job of teachers but also taking an active role in their families on the subject can make the learning process more dynamic.

\section{Kaynakça / References}

Aksan, D. (2000). Her yönüyle dil ana çizgileriyle dilbilim. Ankara: TDK Yay. Aksoy, A. Ö. (1988). Atasözleri ve deyimler sözlü̆̈̈̈ 1-2. İstanbul: İnkılâp Kitabevi.

Akşit, B. T. (1992). Medikal araştırmalarda etik sorunlar. Türk Tabipler Birlĭgi Sağ lı Kongresi. Ankara.

Aktaş, Ş. T. (2004). Seçme atasözleri ve eleştirmeli açıklamaları. Ankara: Akçağ Yayınları. Arslan, E., Dönmez, F. Z., Davarcıŏ̆lu, S., Kara-Eren, C., ve Güngör-Aytar, F. A. (2019). Okul öncesi öykü kitaplarındaki deyimler ve çocukların bu deyimlere ilişkin algiları. Amasya Üniversitesi Ĕ̆itim Fakültesi Dergisi, 8(2), 315-351.

Artun, E. (2004). Türk halk edebiyatına giriş. İstanbul: Kitapevi Yayınları.

Berg, B., ve Lune, H. (2019). Sosyal bilimlerde araştırma yöntemleri (9. Baskıdan çeviri, 4 b.). (A. Arı, Çev.) Konya: Eğitim Yayınevi.

Bilir, S., ve Bal, S. (tarih yok). Kütahya il merkezinde anaokuluna giden ve gitmeyen 4-6 yaşlar arasındaki çocukların kullandıkları ifadelerin sözdizimi yönünüden incelenmesi. Ya-Pa 6. Okulöncesi Eğitimi ve Yaygınlaştırlması Semineri Kitapçı̆̆. içinde İstanbul: Ya-Pa Yayın.

Bowling, A. (2002). Research methods in health: investigating health and health services (2 b.). Philadelphia, PA: McGraw-Hill House.

Bulut, M. (2013). Türkçe eğitimi ve öğretiminde dil ve kültür aktarimi araci olarak atasözleri ve deyimlerin önemi. Turkish Studies -International Periodical For The Languages, Literature and History of Turkish or Turkic, 8(13), 559-575.

Cemşidov, Ş. (1996). Elimizin söz boğçası. Bakü, Azerbaycan.

Çokluk, Ö., Yılmaz, K., ve Oğuz, E. (2011). Nitel bir görüşme yöntemi: Odak grup görüşmesi. Kuramsal Ĕ̈̆itimbilim, 4(1), 95-107. 
Çoruk, H., ve Çakır, R. (2017). Çoklu ortam kullanımının ilkokul öğrencilerinin akademik başarılarına ve kaygilarına etkisi. Turkish Journal of Computer and Mathematics Education, 8(1), 1-27.

Dik, T. (2010). Atasözlerinde adil dünya inanc1. Millî Folklor, 22(88), 28-32.

Drigas, A., Kokkalia, G., ve Lytras, M. (2015). Mobile and multimedia learning in preschool education. Journal of Mobile Multimedia, 1(1\&2), 119-133.

Duman, M. (2012). Türk atasözlerinde "ölüm". Prof. Dr. Fikret Türkmen Armağanı. Ed. Alimcan İnayet-Zeki Kaymaz.

Edmunds, H. (2000). The focus group research handbook. New York: McGraw-Hill.

Elçin, Ş. (1986). Halk edebiyatına giriş. Ankara: Sevinç Matbaası.

Haciyev, T. (1990). Şerimiz, nesrimiz, edebi dilimiz. Bakü, Azerbaycan.

Jonassen, D. H., Howland, J., Moore, J., \& Marra, R. M. (2003). Learning to solve problems with technology: A constructivist perspective. Upper Saddle River, NJ: Merrill Prentice Hall.

Kert, S., ve Tekdal, M. (2018). Alanyazındaki tasarım ilkelerine uygun olarak geliştirilmiş çokluortam ders yazilımının lise düzeyi fizik öğretiminde akademik başarıya ve kalıclığa etkisi. Pamukkale Üniversitesi Eğitim Fakültesi Dergisi, 1(23), 120-131.

Kulıç-Çakmak, E. (2007). Çoklu ortamlarda dar boğaz: aşırı bilişsel yüklenme. Gazi Eğitim Fakültesi Dergisi, 27(2), 1-24.

Kitzinger, J. (1995). Qualitative research: Introducing focus groups. BMJ, 311, 299-302.

Kroll, T., Barbour, R., ve Harris, J. (2007). Using focus groups in disability research. Qualitative health research, 17(5), 690-698.

Krueger, R. (1994). Focus groups: A practical guide for applied research. London: Sage.

Lever-Duffy, J., McDonald, J. B., ve Mizell, A. P. (2003). Teaching and learning with technology. New York, USA: Allyn and Bacon.

Lin, T. C., Lin, T. J., ve Tsai, C. C. (2014). Research tredns in science education from 2008 to 2012: A systematic content analyisis of publications in selected journals. International Journal of Science Education, 36(8), 1346-1372.

Marshall, C., ve Rossman, G. B. (2014). Designing qualitative research. New York: Sage.

Mayer, R. E. (2009). Multimedia learning (2nd ed.). New York: Cambridge University Press.

Morgan, D. (1997). Qualitative research methods: Focus groups as qualitative research. California: Sage.

Önder, M. (2011). Okul öncesi dönem çocuklarının aile eğitimi. Çukurova Üniversitesi İlahiyat Fakültesi Dergisi, 15(1), 377-386. 
Preradović, N. M., Unić, D., ve Boras, D. (2014).Multimedia literacy in preschool and primary education.2nd International Conference on Computer Supported Education.

Rogers, P. L. (2001). Designing instruction for technology enhanced learning. London: IRM Pres.

Schwier, R. A., ve Misanchuk, E. R. (1994). Interactive multimedia instruction. Englewood Cliffs, New Jersey: Educational Technology Publications.

Tashakkori, A., ve Teddlie, C. (2010). Sage handbook of mixed methods in social \& behavioral research. CA: Sage.

Yanmaz, E., ve Bozdoğan, A. E. (2016). Çoklu ortam kullanımının ortaokul 8. sinuf öğrencilerinin fen bilimleri dersindeki akademik başarılarına etkisi. 4th International Instructional Technologies \& Teacher Education Symposium (s. 21-25). Elazı̆̆: Firat University.

Yıldırım, A., ve Şimşek, H. (2005). Sosyal bilimlerde nitel araştırma yöntemleri [Qualitative research methods in the social sciences] (5 ed.). Ankara: Seçkin Yayıncllk.

\section{Kaynakça Bilgisi / Citation Information}

Kaban, A. ve Bulut, A. (2020). Atasözü ve deyimlerin çoklu ortam materyalleriyle somutlaştırılmasının okul öncesi eğitime etkisi. OPUSUluslararası Toplum Araştırmaları Dergisi, 16(30), 2684-2709. DOI: 10.26466/opus.749822 